\title{
Erratum to: Natural vanadium-containing Jeju ground water stimulates glucose uptake through the activation of AMP-activated protein kinase in L6 myotubes
}

\author{
Seung-Lark Hwang • Hyeun Wook Chang
}

Published online: 22 November 2011

(C) Springer Science+Business Media, LLC. 2011

Erratum to: Mol Cell Biochem

DOI 10.1007/s11010-011-1062-4

In the original article Fig. 6a is not correct. We reprint the complete corrected figure here below. Everything else in the paper remains correct.

The online version of the original article can be found under doi:10.1007/s11010-011-1062-4.

S.-L. Hwang · H. W. Chang ( $₫)$

College of Pharmacy, Yeungnam University,

Gyeongsan 712-749, Republic of Korea

e-mail: hwchang@yu.ac.kr 


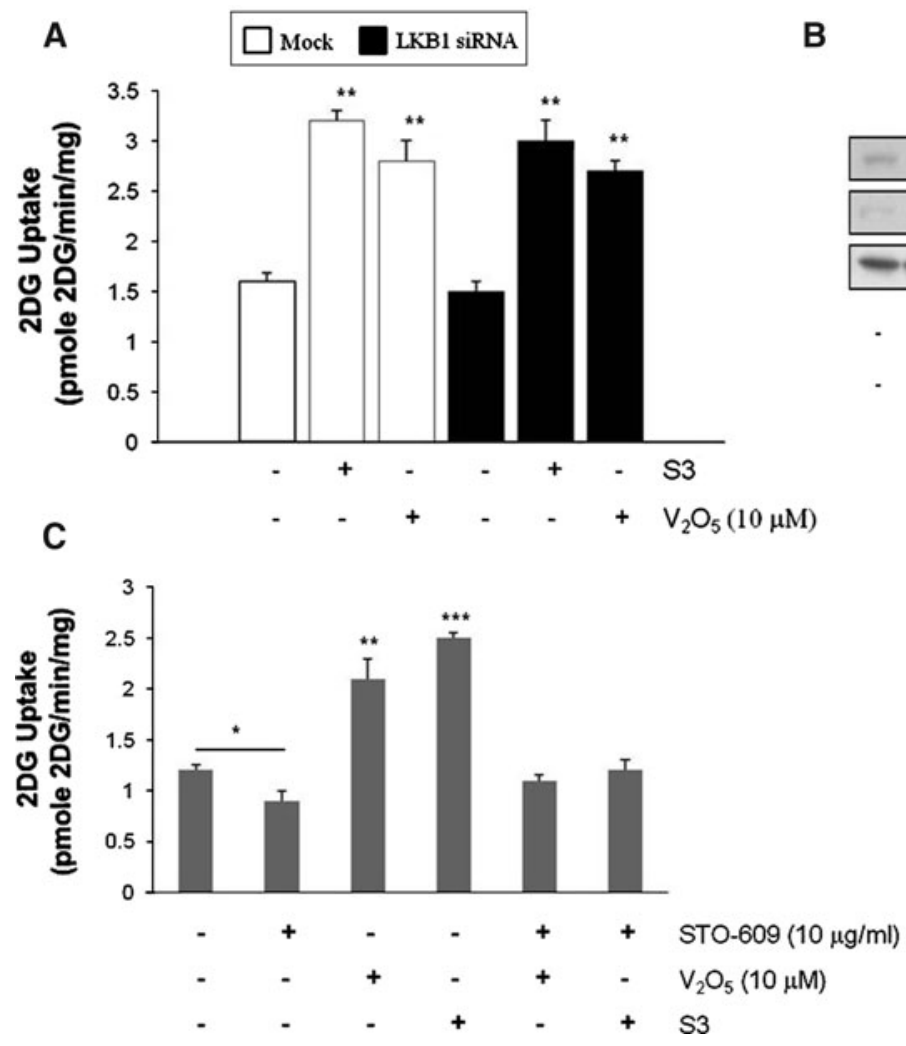

Fig. 6 S3-activated AMPK induces glucose uptake through CaM$\mathrm{KK} \beta$-dependent signaling. a L6 myotubes were pretreated for $48 \mathrm{~h}$ with two siRNAs targeted against LKB1 or a non-related siRNA (mock) (each siRNA at $100 \mathrm{nM}$ ). Cells were then incubated with S3, $10 \mu \mathrm{M} \mathrm{V}_{2} \mathrm{O}_{5}$, or vehicle. Glucose uptake was measured in the L6 myotubes as described in the "Materials and methods." Data were compiled from four independent experiments and are expressed as means \pm SE. $* * P<0.01$, compared to the DDW control. b, c Cells were preincubated with $\mathrm{S} 3$-mediated media for 1 week and then treated with STO-609 $(10 \mu \mathrm{g} / \mathrm{ml})$, or pretreated with $10 \mu \mathrm{g} / \mathrm{ml}$ of CaMKK inhibitor (STO-609) for $30 \mathrm{~min}$ and then treated with $10 \mu \mathrm{M}$ $\mathrm{V}_{2} \mathrm{O}_{5}$ for $2 \mathrm{~h}$. Cell lysates were prepared and subjected to immunoblot analysis using specific antibodies against p-AMPK, p-ACC, and $\beta$ tubulin. Glucose uptake was measured in the L6 myotubes as described in the "Materials and methods." Data were compiled from four independent experiments and are expressed as means \pm SE. $* P<0.05, * * P<0.01$ or $* * * P<0.001$ compared to the DDW control 